\title{
Women in the Parliament of Tunisia: A Case Study of Factors that Influence Female Representation
}

\author{
Kimberly S Adams \\ East Stroudsburg University of Pennsylvania
}

\begin{abstract}
.
In Tunisia's latest election in 2014, women were elected to 68 of the 217 seats in the lower chamber of parliament. Hence, women hold $31.8 \%$ the seats in the Majlis Nawwab ash-Sha'ab/ Assembly of People's Representatives (IDEA, 2019) which is one of the highest percentages of women in parliament within the MENA region in 2019. This research examines Tunisia's Jasmine Revolution and its possible impact on the share of women in parliament. Further, this research explores political factors including the adoption and implementation of gender quotas, Tunisia's level of democracy and its proportional representation electoral system, as factors that influence female representation. The findings indicate that all four factors have some influence on the presence of women in parliament in Tunisia.
\end{abstract}

Keywords: Tunisian Women; Tunisian politics; democracy; proportional representation; gender quotas 